\title{
Analysis of New Industrialization and Chinese Strategic Trade Policy
}

\author{
Ting Dai ${ }^{1}$
}

\author{
${ }^{1}$ Jiangxi College of Foreign Studies, Nan Chang, Jiang Xi, 330099
}

KEYWORDS: New Industrialization; Strategic Trade Policy; Sustainable Development

\begin{abstract}
This paper chooses Chinese new road to industrialization and strategic innovation study purpose is to elaborate on industrialization and industrialization path theory, under the correct analysis of the traditional path of industrialization characterized by the premise, explore a new road to industrialization theory, of taking a new road to industrialization framework, China's industrialization strategy proposed to complete the task, to provide a theoretical basis and practical guidance to further modernize. Proposed exploration and development strategy of China's new road to industrialization, lessons for the system of international and domestic traditional road to industrialization, China's economic development to solve the economic and social disharmony, uncoordinated regional structures, waste of resources and serious environmental pollution and other issues, having important practical significance.
\end{abstract}

\section{Introduction}

Industrialization is the main task of China's current economic development. Economic development must go through the stage of industrialization. From a historical point of view of economic development in developed countries, recognized as the world's first industrialized countries in the British half of the 19th century industrial revolution, industrial production increased by 3 times. Subsequently, Germany, France, Britain and the United States have followed the footsteps achieved industrialization. Early 20th century, Japan and Russia also through industrialization and become a world power. The world's developed countries and both are realized industrialized countries. On the contrary, they are all developing countries, industrialized countries have not realized. As a developing country, China apparently did not complete the task of industrialization.

China must develop the era decision to take a new road to industrialization. After the 20th century, especially in the 21st century, information technology as the leading high-tech large-scale emergence of the scientific and technological revolution has brought world-wide, which caused the rapid development of information industry as the leading high-tech industries, so that the world is facing a new industrial revolution and the industrial restructuring. The increasing trend of economic globalization, China's accession to WTO have been integrated into the world economy, international division of labor system in one. In this context, our country must conform to the trend of international economic development, make full use of international resources, give play to the advantage, through the introduction of advanced foreign technology, through digestion, absorption, transformation, innovation, accelerate the process of industrialization and economic development, shorten the developed national gap, and embark on a new road to industrialization.

Therefore, China should basically accomplish industrialization, we must handle the relationship between economic development and population, resources and the ecological environment. Pay attention to scientific and technological progress to promote economic growth, greatly improve the economic efficiency, conservation and rational use of resources, protects the ecological environment, the implementation of sustainable development strategies. But also do everything 
possible to expand employment, and unswervingly follow the "high technological content, good economic returns, low resources consumption, little environmental pollution and human resource advantages into full play," the new road to industrialization.

\section{Relations between Strategic Trade Policy and the New Industrialization Strategy}

First, how to choose to support the industry, we must first consider the purpose of strategic trade policy. Any trade policy is based on national interests, strategic trade policy as well. Strategic trade policy to encourage exports of specific products to limit imports of foreign products, primarily for the interests of both; to win high monopoly profits of foreign companies in order to improve their welfare, increase international market share of export products to promote industrial growth and structural optimization. From strategic trade policy purposes, we can easily come to choose one of the bases of strategic industries is to see if the presence of a large number of industrial rents.

Next, choose the strategic trade policy is bound to be affected by industrial domestic industrial structure, and the choice of strategic industries, in turn, will affect the domestic industrial structure. Therefore, in trade policy for strategic industrial choices must be combined with the national macro-industrial policy, coordination leading industries, the development of basic industries, declining industries to optimize their industrial structure. Domestic industry status and resources ABUNDANCE factors also must be considered a strategic industry of choice.

Third, pay attention to the external economic effects in the industrial select strategic trade policy, that research and development activities or experience in an enterprise to other enterprises whether it will generate spillover. Protection or export subsidies and other policy support to other sectors of the economy that produce large amounts of high-tech industry technology spillover can increase national income; foreign governments to support and protect these industries may cause the loss of the domestic industry beneficial spillover. Of course, since there is no spillover market price, according to this standard to measure strategic industries have a certain degree of difficulty.

Finally, when the Government adopted strategic trade policy, domestic tariff measures will reduce consumer welfare, subsidies and other measures may harm the development of other industries. Therefore, the choice of strategic industry must pay attention to cost and benefit analysis.

Therefore, in accordance with the Strategic Trade Policy of the target industry selection constraints, the theory that the high-tech sector that best meet the above conditions. This coincides with the dominant ideology of the New Industrialization Strategy.

\section{Strategic Trade Policy Measures Accelerates the Implementation of The Strategy of the New Industrialization}

First, select a number of strategic industries, the implementation of strategic trade policies, and the implementation of various policy instruments depending on the characteristics of the target industries. From domestic and international economic environment currently facing our country, our country does not yet have the full implementation of the strategic trade policy conditions, but in the local areas in which we already possible to implement strategic trade policy. Specifically, obviously have spillover benefits in accordance with the strategic trade policy protected sectors, economies of scale and easy to form a natural monopoly characteristics, our government should give priority to choose electronics, telecommunications, computer software, automotive, aerospace, new materials, new energy, bio-engineering, shipbuilding, electric power and other strategic sectors to implement strategic trade policy. Through the effective protection of these strategic sectors of both the pace of development in these sectors, but also can promote the rapid development of other 
industries through their radiation and engine effect, thereby fundamentally improve the overall quality of the national economy, the realization of our national sustainable economic development. In determining the strategic objectives based on the industrial sector, according to the different goals of different sectors of the life cycle and the level of international competitiveness, taking into account the division factor of the domestic industry, choose to apply different and appropriate strategic trade policy instruments. For example, in the growth stage and have economies of scale industries, such as aircraft manufacturing, semiconductor, telecommunications, new materials, bio-engineering and marine development and other sectors (these sectors to some extent determine the future of countries in the international competitive position), can implement strategic trade policy tariff policy, and the implementation of R \& D subsidies to encourage venture capital support policies: the maturing of the industry has economies of scale, such as automotive, electrical, mechanical and electrical products, machinery and transportation equipment industries (these competitive advantage industry, mainly in developing countries), we can focus on the implementation of the strategic trade policy export policy to encourage enterprises to actively explore the international market for foreign exchange earnings.

Second, to further enrich and improve the socialist market economic system, speed up the establishment and improvement of modern enterprise system. At present, China only initially formed the basic framework of the socialist market economic system is far from perfect. For example, an important function of the market mechanism is to promote the flow of resources from low efficiency sector cost-effective sector, in order to achieve a combination of factors of production optimization and upgrading of industrial structure. However, there are still state-owned enterprises, "easy to enter and exit difficult" issue. "Entering the easy" outstanding performance in a large number of low-level duplicated investment, causing a great waste of resources, increasing the difficulty of industrial restructuring. "Exit difficult" More generally, the performance of loss-making enterprises are not free, timely and out of production, reorganization of resources. Both have shown that the low level of investment decisions and capital equity market in China. This reflects the autonomy of state-owned enterprises have not yet been fully implemented, the impact of administrative intervention is still very great. It also reflects our market system, including the property market, factor market, capital market is not yet mature, developed, to be further nurture and develop. Government policy guidance on improving market mechanisms to promote the rational flow of resources, can play a significant role. The Government may, "long-term" industries or inefficient industries exit the business preferential treatment, such as when and if the enterprise archive out of the old equipment, making new investment, you can get priority in proportion to the use of special or preferential loans or depreciation rates, or take the form of government purchases of excess capacity, it gives some financial compensation. This is actually the way the market is both equity capital, but also the government and the market conduct coordinated manner. Again, China's capital market has not really play an important role in optimizing combination of factors of production, capital market executive-led distort the basic resource allocation functions. Therefore, the Government departments to completely change the kind of one-sided view of the capital market solely as the financing tool, really establish a long-term point of view, from a perfect market system, changes in resource allocation mechanism, improve the overall quality of the national economy point of view, on the Capital Market and nurture development of.

Third, to increase R \& D investment to accelerate the pace of scientific and technological achievements in industry. At present, China's science and technology investment accounted for GDP ratio of less than $1 \%$, while in developed countries the ratio is $2 \%-3 \%$; our $\mathrm{R} \& \mathrm{D}$ growth rate has been lower than GDP growth, while the developed countries this ratio generally higher than the 
GDP growth of $2 \%-3 \%$. Meanwhile, China's annual scientific and technological achievements created to less than $20 \%$ of new products, industrialization can only be formed by $3 \%$, significantly lower than similar ratios in developed countries. Therefore, our government departments and various enterprises should strengthen the $\mathrm{R} \& \mathrm{D}$ investment, continuous technological innovation leading industry sectors: industry and trade through a combination of ways to establish large-scale industry and trade group, accelerate scientific and technological achievements of the pace of industrialization. Meanwhile, the government departments and various enterprises to continue to pay attention to the absorption of foreign advanced technology achievements, digestion, promotion and innovation, to play its leading role, narrowing the technological gap of the leading industrial sector and between the Western countries

\section{Conclusion}

Under the guidance of the scientific concept of development, this paper explores theories industrialized agricultural economy, industrial economy and the knowledge economy ternary economic. According to this theory, the framework of China's new road to industrialization must be considered in all aspects of economic and social development, social harmony and sustainable development of resources. Thus, a set of index system of the degree of realization of new industrialization, including economic development, structural change, technological advances and information technology, efficiency and efficiency, comprehensive utilization of resources, social development and human development indicators. Such indicators based on a relatively complete system of integrated evaluation method for the degree of realization of New Industrialization in China all-round judge. New road to industrialization is different from any previous road to industrialization of the country, to complete our task of industrialization must be innovation in the development strategy, introducing sustainable development, technological innovation, information technology to stimulate industrialization, structural optimization and upgrading, human resource utilization eight strategies.

\section{Reference:}

[1] Jomo. K. S. Southeast. Asia's Misunderstood Miracle-Industrial Policy and Economic Development in Thailand, Malaysia and Indonesia [M] .West view Press 1997.

[2] Chennery H. Industrialization and Growth: A Comparative Study [M]. Oxford. University Press, 1986.

[3] RR. Palmade, "French Capitalism in Nineteenth century", New York: Barnes and Noble, 1972.

[4] Hill, H. Indonesia's Industrial Policy and Performance: 'Orthodoxy' Vindicated [R]. Economic Division Working. Paper 95, 1,1995. 